\title{
Public Policies and Institutions Influencing South Africa's Outward Foreign Direct Investment
}

\author{
Albert Edgar Manyuchi ${ }^{a, *}$ and John Ouma Mugabe ${ }^{b}$ \\ ${ }^{\mathrm{a}}$ Department of Political Sciences, University of Pretoria, Pretoria, South Africa; \\ ${ }^{b}$ Department of Engineering and Technology Management, Graduate School of Technology Management (GSTM), \\ University of Pretoria, Pretoria, South Africa \\ *Correspondence to: albertedgar.manyuchi@gmail.com
}

\begin{abstract}
South Africa is among the leading outward foreign direct investor nations from emerging countries in the world. The country's transnational corporations have investments in all the seven continents. The integration of the country into the global economic and trading system boosted its outward foreign direct investment (OFDI). Since the 1990s, South Africa has adopted a wide range of national policies, created institutions and become a party to international treaties that have remarkably influenced her OFDI. This study examines the public policies, institutions and political factors that influence South Africa's OFDI since 1994. The country's OFDI is influenced by diplomatic relations, implicit public policies and indirect institutions, which is similar to developed countries but different to other emerging countries. The study is stimulated by three factors - a few studies have focused on factors influencing OFDI from African countries; scanty empirical evidence on factors that influence South Africa's OFDI; and the infancy state of African scholarship on the nexus between diplomacy and international investment. This study contributes to growing research on the role of diplomacy in influencing the direction and content of OFDI. Future studies should examine whether South Africa would benefit more through influencing OFDI following the approaches of other emerging countries.
\end{abstract}

\section{Introduction}

South Africa's outward foreign direct investment (OFDI) has increased since the end of apartheid in 1994. This is largely because the post-apartheid government lessened restrictions on capital movements than before, enabling South African transnational corporations (TNCS) to resort to OFDI to maintain and increase competitiveness in global markets (UNCTAD 1999). The outflows of foreign direct investment (FDI) from South Africa generally consist of equity capital, intracompany loans and reinvested earnings (UNCTAD 2010). South African direct investments in other countries can be considered FDI if they establish a controlling equity of at least $10 \%$ in the invested entity or subsidiary (IMF 2009), have a long-time horizon and are not done for speculative purposes but rather to serve the domestic markets, exploit natural resources or provide platforms to serve the world markets through exports (Jensen 2003).

South African OFDI are generally market-seeking, resource seeking, efficient-seeking and strategic-asset seeking (Games 2004; Gelb 2010, 2014). The flows of South African OFDI contribute to employment creation, technological progress, increased productivity and 
ultimately economic growth in host countries (Mwillima 2003). OFDI provide capital that may not be easily available in host countries and facilitates technology transfer between South Africa and host countries. Because of these significant economic benefits, African countries such as the Democratic Republic of Congo (DRC) and Zimbabwe have attempted to attract OFDI from South Africa contemporaneously with flows from other countries (Webb 2007; Kazunga 2014). For instance, in a quest to attract South African OFDI during a state visit to South Africa, the Minister of Finance and Economic Development of Zimbabwe Patrick Chinamasa stated that:

We (Zimbabwe) have lots of economic challenges, but if one looks at them with a positive mind, they are equally economic opportunities to investors. We are here to say to our South African brothers, sisters, local and international companies, seize these opportunities for your business expansion or growth. Zimbabwe is welcoming you to start business in a peaceful, conducive and environmental friendly atmosphere. (Kwinika 2015)

Although a number of studies have assessed the consequences of international capital flows, including FDI, on state's sovereignty and the political system (democracy/liberal or autocracy) that obtain in a given country (Stopford and Strange 1991; Strange 1996, 1988, 1998; Jensen 2003), they have erroneously taken a reductionist approach that reduces FDI flows to financial flows. As a result, most existing studies have inadvertently focused on the effects of FDI (financial flows) on host states. Using this optical foci, Jensen $(2003,587)$ contents that 'the need to attract FDI pressures governments to provide a climate more hospitable to foreign corporations - potentially altering patterns of domestic economic policy and possibly even challenging the de-facto sovereignty of nation-states and the capacity for democratic governance'. However, there is dearth of empirical evidence on political factors, policies and institutions influencing OFDI. Thus, the public policies, institutions and political factors that influence South African OFDI have remained unexplored in current studies.

This article empirically explains the public policies, institutions and political factors influencing South African OFDI. In this regard, South Africa is a case study of a home country to outflows of FDI. The key research questions this particular study addresses are: what public policies, national institutions and political factors influence South Africa's OFDI flows to other countries? Are South Africa's approaches to OFDI different from other countries, especially emerging countries? For this study, 'public policies' are formal rules, legislation and regulations that stimulate or facilitate FDI outflows; and 'institutions' are a set of formal government apparatus (organisations) involved in OFDI from South Africa. Similarly, 'political factors' relate to diplomatic actions carried out by states through government that facilitate outflows of FDI to, or minimise risks of investing in, a given country.

The article is organised as follows. Section two discusses the conceptual framework guiding the analysis, and methodology deployed in conducting the research and analysis for the study. It is followed by some stylised facts about South African OFDI, specifically an examination of the volume or quantitative trends and destination of South Africa's OFDI. The section that follows provides a detailed analysis of the public policies and institutions that influence the country's OFDI, followed by a section on the political factors that influence South Africa's OFDI. The last two sections examine whether the manner in which 
South Africa influences OFDI is similar to other countries, especially emerging countries, and the conclusion.

\section{Conceptual framework and methodology}

Conceptually, the researchers approach the issue of institutions and policies that influence South African OFDI from a predominantly state-centred political and legal-institutional perspective (Ikenberry 1988; North 1990). The taxonomy of South African institutions that influence OFDI includes direct and indirect institutions. Whereas direct institutions have an explicit policy and legal mandate on OFDI and their activities have a direct impact on outflows of FDI, indirect institutions have an implicit policy and no direct legal mandate on FDI and their actions on other 'issue-areas' coincidentally affect OFDI.

Therefore, public policies and institutions influence OFDI in two different ways. Direct institutions and explicit policies influence outward flows of FDI through active regulation, which includes clear incentives as well as sanctions for non-compliance. Indirect institutions and implicit policies influence OFDI through passive regulation and the incentives and/or sanctions are relatively not that clear. In addition, the influence of public policies on OFDI is largely dependent on the capacity of institutions to enforce these.

The examination of 'political factors' that influence OFDI is carried out through the diplomatic and rule-based approaches. The diplomatic approach refers to ad hoc and flexible interactions carried out by governments with other governments and non-state actors that influence OFDI. Thus, an explanation of South Africa's use of government apparatus to build positive diplomatic and political relations with other countries and how this influences OFDI is provided. In addition, an explanation of the effects of South Africa's participation in regional and international organisations and how this influences OFDI is provided.

Noteworthy, the diplomatic activities that state entities engage in may not necessarily be explicitly and exclusively for facilitating OFDI. In actual fact, outflows of OFDI may be viewed as benefits arising out of successful diplomatic manoeuvres that oftentimes may have been intended at achieving other aims. Anecdotal evidence shows that some ad hoc interventions by the state to generally promote trade relations may have an effect on OFDI.

The second approach that the country uses in passively facilitating OFDI is the rule-based approach, which is closely related to and is oftentimes facilitated by the diplomatic approach. The rule-based approach is based on the use of investment treaties or agreements such as Bilateral Investment Treaties (BITs), Double Taxation Agreements (DTAs), Memorandum of Understandings (MOUs) and other multilateral treaties. These facilitate, promote and protect South African direct investments in signatory host states. In practice, the rule-based approach is employed when South African TNCs point out the existence of BITs, DTAs, MOUs or multilateral treaties that the host state would have signed with South Africa or internationally, then demands protection of investment on the basis of such instruments. 
Methodologically, this research is qualitative; and data from secondary literature sources and interviews were used to examine the political factors, public policies and institutions influencing South Africa's OFDI. The secondary literature included published articles and reports on South Africa's OFDI, South Africa's investment policy documents, legal statutes on investments, treaties, agreements, memorandums of understanding and operational and programmes plans. The secondary literature was gathered through contacting by calling or emailing officials and representatives of government departments, civil society and private sector firms.

Primary data were gathered through 57 individual in-depth semi-structured interviews carried out with government officials, employees of TNCs and members of the civil society as part of a doctoral research carried out between 2013 and 2015. The interviewees were purposely selected on the basis of their understanding of the firms, policies and institutions involved in South Africa's OFDI. The snowball technique involving a key informant suggesting other interviewees that were followed up and interviewed was employed.

For this article, data were primarily processed using ATLAS.ti 7 for Windows software package. Data analysis was carried out electronically using Excel spreadsheets which enabled triangulation of theme-based data collected from interviews and secondary literature.

\section{Some stylised facts about South Africa's OFDI}

The evolution and composition of South Africa's economy should be viewed using 'double optical foci': the apartheid era, and the post-apartheid era (UNCTAD 2005). The apartheid era economy was characterised by sanctions that kept the country out of the mainstream world trading system and no or very limited participation in the international investment landscape (Klein and Wöcke 2007). Before 1994, the country was excluded from major international investment regimes and denied destinations for OFDI.

The end of apartheid led to the relaxation of economic sanctions and the liberalisation of the South African economy. This led to a paradigm shift in the corporate strategy of South African firms, from conglomeration to focusing on core business, and this provided the impetus for the diversification of operations internationally (UNCTAD 2005. These political and economic changes resulted in South Africa becoming one of the emerging global investors, with significant OFDI flows and OFDI stocks. The country's OFDI flows and stocks from 2010 to 2014 are presented in Table 1.

Table 1. South Africa's OFDI Flows and Stocks from 2010 to 2014.

$\begin{array}{ccc}\text { Year } & \text { FDI outward flows (US\$ millions) } & \text { FDI outward stocks (US\$ millions) } \\ 2010 & -76 & 83,249 \\ 2011 & -257 & 97,051 \\ 2012 & 2988 & 111,780 \\ 2013 & 5620 & 128,681.4 \\ 2014 & 6937.5 & 133,936.2\end{array}$

Source: UNCTADSTAT (2016 UNCTADSTAT. 2016. 
The net OFDI flows from South Africa were affected by the global financial meltdown in 2010 and 2011 but have since recovered and continued to increase from 2012 to 2014 as presented in Table 1. This means that South African TNCs are increasingly getting integrated into the world economy. Table 1 further shows that the OFDI stocks, which are generally less volatile and more stable than flows, have been on the increase from 2010 to 2014. Therefore, South Africa has significant volumes of outward FDI stocks.

Nishiura (2009) points out that the OFDI stock of South Africa at the end of 2002 represented ' $0.4 \%$ of the world total, $3.5 \%$ of the developing world, $66.0 \%$ of the whole of Africa and $71.7 \%$ of sub-Saharan Africa'. Similarly, UNCTAD (2010) reports that between 2006 and 2010 'South Africa's investments accounted for an average of $0.35 \%$ of global outward investment. During this period, $2.27 \%$ of the outward FDI stock from developing countries came from South Africa'.

South African TNCs have invested in all regions of the world (as presented in Figure 1). UNCTAD (2016) reports that at the end of 2014, South Africa's OFDI stocks to the world stood at USD 144 billion, of which USD 66 billion was invested in developed countries and USD 78 in developing and transition economies. Figure 1 shows that Europe holds the largest share of South African direct investments, followed by Africa and Asia respectively and Oceania has the least share of South Africa's direct investments. In contrast to the Asia and overall Africa situation presented in Figure 1, UNCTAD (2016) reports that the end of 2014, USD47 billion and USD26 billion of South African OFDI stocks were in East Asia and Africa, respectively, meaning that South Africa's OFDI stocks in Asia have outpaced those in Africa.

Figure 1. South African OFDI by region (R millions), 31 December 2011. Source: South African Reserve Bank 2013.

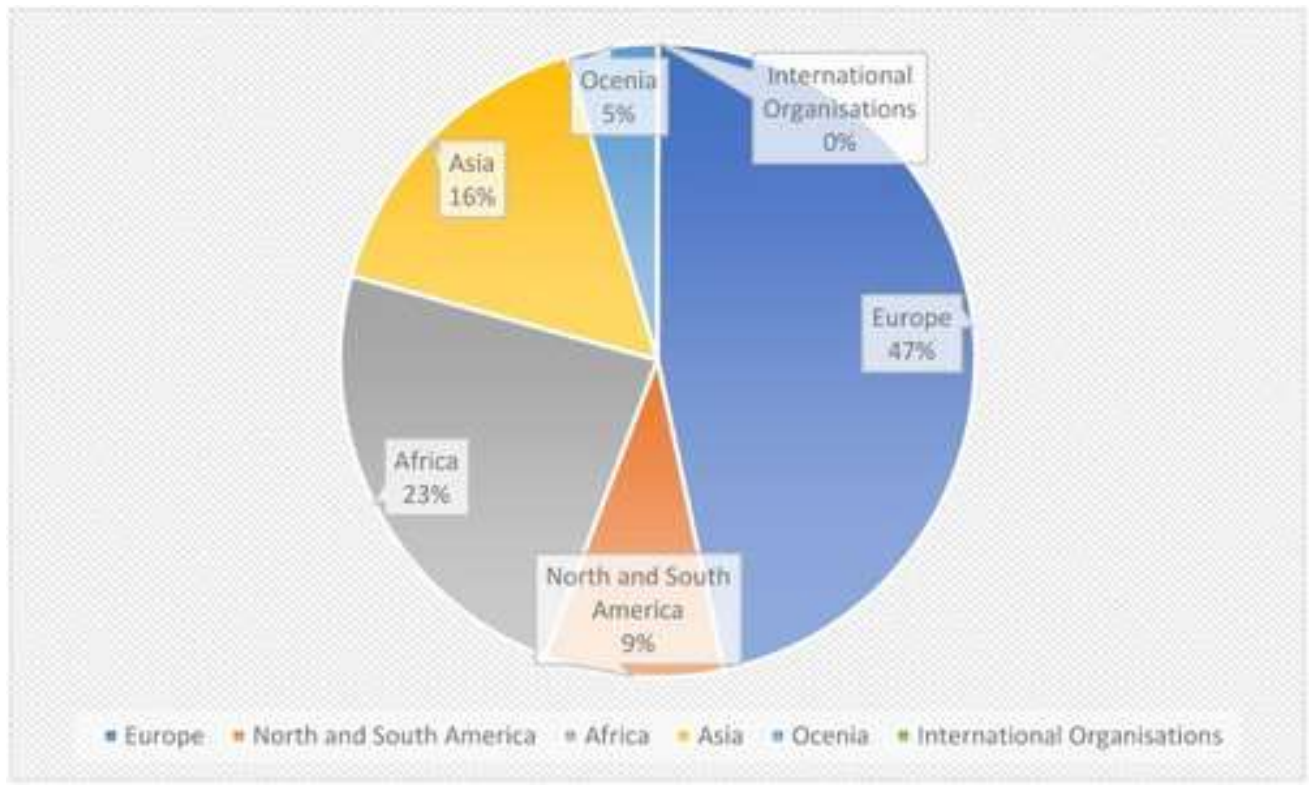

Direct investments from South Africa to North and South America have decreased over time. Gelb (2010) points out that in 2002 South African investments in North and South 
America were second to Europe, that is, much higher than those made in Asia and Africa. The South African Reserve Bank (SARB) reports that, in 2002, the share of South African FDI outward stock in the Americas stood at 12.2\%. Gelb (2010) observed a decrease in these stocks in 2003 and 2008 from 9.4\% to 7.4\%, respectively. The country's direct investments in North and South America declined because of the US government's active opposition to apartheid and its implementation of sanctions against the South African government before 1994. However, the investments have failed to grow significantly after the new dispensation.

Whilst South African investments in North and South America were declining, the importance of Asia and Africa as an outward investment destinations for South African investors have increased over time. UNCTAD (2011) reports that the share for Africa in South Africa's outward FDI stock rose from $8 \%$ in 2005 to $22 \%$ in 2009. Trade and Industry Minister Davies (2012) stated that the 'total South African direct investments to the rest of Africa increased from R3.8 billion in 1994 to R115.7 billion in 2009', thus multiplying 31 times and covering 36 African countries. In his 2013 Budget Speech, Finance Minister Pravin Gordhan noted that, during the period 2009-2013, the SARB approved over 1000 large investment projects in 36 African countries. Likewise, in his 2014 budget speech, Gordhan noted that South Africa had become the second-largest developing country investor on the African continent.

In terms of destinations, Table 2 shows the top recipient or host countries for South African OFDIs.

Table 2. The top destinations of South African OFDI (R million) 31 December 2011.

Region/economy

United Kingdom

Luxemburg

Austria

Russia

Netherlands

Germany

Switzerland

USA

Canada

Bermuda

China

Hong Kong

Japan

Singapore

Mauritius

Mozambique

Nigeria
Total direct investment ( $R$ million) 2011

Europe

148,784

63,595

45,386

20,213

19,344

14,121

10,484

North and South America

34,160

13,234

1477

Asia

103,777

4225

1019

2594

Africa

80,740

23,829

14,456 
Region/economy

Namibia

Zimbabwe

Botswana

Swaziland

Lesotho

Oceania

Australia
Total direct investment ( $R$ million) 2011

11,719

9762

7799

3753

2264

36,261

Source: Author, data from SARB (2013).

In terms of economic blocks, other than the Southern African Customs Union and the Southern African Development Community (SADC), South African outward FDI has also penetrated other countries that constitute the BRIC (Brazil, Russia, India and China) bloc. In 2011 , the South African share of investments in the BRIC stood at $20 \%$, which is less but very close to the outward FDI stock in other African countries which stood at $23 \%$ (UNCTAD 2013). Furthermore, among BRIC countries, South Africa shows the largest share of intraBRIC investment, and in 2011 'one-fifth of the outward FDI stock of South Africa was located in BRIC [countries], mainly in China'. The second-largest investments were in the Russian Federation, followed by India and Brazil (UNCTAD 2013)

\section{Public policies and institutions influencing South Africa's OFDI}

The study findings show that South Africa does not have an explicit national policy or direct national institutions influencing OFDI to other continents except Africa. Intrinsically, OFDI is advanced through a set of implicit policies and indirect institutions. These passively regulate outflows of FDI from the country. The implicit policies that influence OFDI from South Africa are those relating to foreign exchange. Intrinsically, Gelb $(2010,5)$ asserts that 'the only regulation of OFDI is that South African residents, including corporations, are still subject to exchange controls'.

Institutionally, the President of South Africa is the highest authority empowered by Section 9 of the Currency and Exchange Act (Act No. 9 of 1933) 'to make regulations in regard to any matter directly or indirectly relating to, or affecting, or having a bearing upon, currency, banking and exchanges' (Exchange Control Manual 2014). However, these powers are delegated to the Minister of Finance and the National Treasury, and they are responsible for regulating OFDI through the exchange control policy. In this regard, the Ministry of Finance and National Treasury implicitly influence South African OFDI and TNCs through their formulation of exchange control policies.

However, the Minister of Finance does not implement the exchange control policy directly, but exercise this through delegated authority to various individuals in the line ministry. As such, delegated authority is exercised by the Governor and Deputy Governor of the SARB, and General Manager, Deputy General Manager and Assistant General Manager of SARB's Financial Surveillance Department (FSD). The implementation and administration of exchange control policy fall under the SARB, which was established as the country's central bank in 1921 in terms of Section 9 of the Currency and Banking Act, 1920 (Act No. 31 of 1920), replaced by the South African Reserve Bank Act, 1944 (Act No. 29 of 1944), and 
amended by the South African Reserve Bank Act, 1989 (Act No. 90 of 1989) and the South African Reserve Bank Amendment Act, 2010 (Act No. 4 of 2010).

Within the Reserve Bank, the FSD has duties that directly influence OFDI through its mandate to implement exchange control rules and regulations. The FSD interacts with the National Treasury through a Technical Committee on Exchange Control Issues. The Technical Committee is composed of officials from the FSD and other Reserve Bank departments, and it troubleshoots any operational and systems issues in relation to exchange controls. Thus, the influence of the SARB on OFDI is related to the monetary policy the Bank sets, as well as the implementation of exchange control rules and regulations.

The SARB's FSD interacts with TNCs through 'authorised dealers'. These are legal persons authorised by the National Treasury to deal in foreign currency and matters of foreign exchange, including financial institutions such as banks. Authorised dealers may process and facilitate applications for foreign exchange and foreign bank accounts without reference to the FSD, if these applications fall within the parameters outlined in the Exchange Control Rules. In cases where the amounts to be transferred are higher than the set amount, authorised dealers assist with applications and submissions for approval by the FSD.

Therefore, authorised dealers influence OFDI as they are the institutions that directly interact with TNCs, assessing their applications for money transfers, transferring the applicable acceptable amounts, processing amounts that are not normally allowable through the SARB and receiving transfers of money from investments. Authorised dealers implicitly influence OFDI as conduits that facilitate the movement of funds between the headquarters of TNCS and their subsidiaries, between these companies and their service providers, as well as between firms and their external stakeholders.

Besides institutions and policies for exchange controls, there are other important national institutions that indirectly influence OFDI. The Department of Trade and Industry (DTI) is central in matters dealing with FDI, including OFDI. The DTI makes reference to investment through its mission statement ' ... to provide a predictable, competitive, equitable and socially responsible environment, conducive to investment, trade and enterprise development' (DTI 2014), as well as through its strategic objective that aims 'to create a fair regulatory environment that enables investment, trade and enterprise development in an equitable and socially responsible manner' (DTI 2014). In addition, a special DTI theme on trade, export and investment aims to develop programmes, amongst other activities, and 'focuses on increasing [the] levels of international trade, foreign direct investment, and economic co-operation ... [at the] regional, continental and international levels' (DTI 2014).

Within the DTI, the International Trade and Economic Development Division is responsible for creating the conditions that promote inward and outward investment. Activities that focus on investments are geared to strengthen trade and investment links through, inter alia, handling and signing BITs, DTAs and MOUs and participating in discussions and research on regional and multilateral economic treaties. The BITs that South Africa has signed off implicitly influence OFDI through reciprocal and good relations between the signatory states. South African TNCs generally regard BITs as imperative and directly protective of, as well as a catalyst for, their investments abroad. 
Similarly, DTAs signed by South Africa influence OFDI by South African TNCs through preventing double taxation of firms involved in direct investments with contracting countries. DTAs have also been used by South Africa as a form of tax incentive for its TNCs. In 2013, for example, South Africa announced a review of its DTA with Mauritius to allow for double taxation (UNCTAD 2013). This measure was aimed at limiting OFDI by South African TNCs that are investing in Mauritius, and then use that country as a base to do further investments in Africa. By imposing double taxation, South Africa raised the costs of doing business through Mauritius, and made it easier for companies to make direct investments into Africa.

An important agency that influences OFDI under the DTI is a one-stop facility, Trade and Investment South Africa (TISA), whose services include investment recruitment, providing investment information, facilitating investment, investment aftercare services, promoting domestic investment and outward investment. TISA activities that relate to OFDI include introducing South African TNCs to investment promotion agencies and government agencies in other countries, introducing South African investors to projects and key stakeholders in the private and public sectors abroad, and supporting South African TNCs on projectfinancing and deal-structuring with financial institutions. Prior to 2013, TISA offered limited services and support to South African OFDI into Africa and no support whatsoever to OFDI by South African TNCs to the rest of the world. However, from 2013 onwards, OFDI by South African companies into Africa has become a prime priority area for TISA. But then, this new focus on Africa has an adverse effect of relegating other regions within TISA's scope of activities to positions of lesser importance.

The Department of International Relations and Co-operation (DIRCO), which conducts foreign affairs and bilateral and multilateral co-operation through 46 bilateral and 1 multilateral Africa-focused and stationed missions, 17 missions in the Americas and the Caribbean, 27 missions in Europe, 32 missions in Asia and the Middle East, and 2 multilateral missions abroad also influences South Africa's outward FDI flows (DIRCO 2014). These missions are classified as High Commissions (in Commonwealth countries), Embassies, and Consulates. DIRCO's activities with an influence on outward investment are mainly enshrined in Outcome 11 of the Delivery Agreement, in which the South African government seeks 'to create a better South Africa and contribute to a better and safer Africa in a better world' through an enhanced African agenda and sustainable development, regional integration, reformed global governance institutions, and trade and investment. Thus, DIRCO indirectly facilitates OFDI through building good political and economic relations with other countries, and preparing the terrain for South African investors to smoothly invest in these countries.

Through its focus on economic diplomacy and economic diplomacy training, DIRCO ensures that personnel in South Africa's missions abroad understand economic issues and are wellversed to act as conduits for economic information which may be useful for OFDI. Economic diplomacy undertakings that influence OFDI include activities to increase value-added exports, attract FDI to priority sectors, promote tourism and encourage the removal of nontariff barriers. DIRCO missions host or participate in trade seminars, tourism promotion, and engage with chambers of commerce, high-level investors and relevant ministries. 
The Presidency and the South African Parliament are also important institutions that influence South Africa's outward FDI flows. Whilst Parliament's role is to provide for oversight and accountability, the Presidency is mainly involved in giving policy advice to, and participating in, organised trade and investment delegations abroad. These delegations oftentimes include South African businesspeople. Furthermore, when Parliament debates and accepts an investment law, especially bilateral and multilateral conventions and treaties, the President has to sign them off.

Above and beyond these national policies and institutions at sectoral level, line ministries and departments also play an influential role in investments made by state-owned enterprises (SOEs) abroad. Key government ministries and departments include the Department of Public Enterprises, the Department of Energy, the Department of Minerals and the Department of Environmental Affairs. However, the manner in which these institutions and their policies influence TNCs and OFDI differs from case to case.

South African state-owned TNCs are generally supported by the national institutions before, during and after investments. To exemplify this, during an interview for this study, a DTI official observed that in November 2001, South African President Thabo Mbeki and a trade delegation visited Mali, his entourage including Eskom staff members who used the opportunity to boost Eskom's business deal won through an international bidding process in July 2001 (Interview with DTI Official, 19 August 2014). In addition, sometimes state-owned TNCs receive ad hoc government support, especially when they are in search of resources that are considered of national strategic importance. For example, the South African government gives support to investments that PetroSA makes in other countries (Interview with a PetroSA Official, 3 September 2014).

Although non-state-owned South African TNCs comply with various national policies, including exchange control and tax requirements, the absence of an explicit OFDI policy framework creates a feeling among such companies that they do not get adequate and sufficient support from national public institutions. They also generally view the policies that the state adopts as aimed at simply securing more revenues, rather than caring about their efforts involved in realising these revenues. A Group Five official commented:

There are some countries where we go out there on our own as a business entity without much support from the South African government, unlike SOEs. Also, we sometimes try to pull in the government later, after investing - at times with success, and at times without success. (Interview, 13 August 2014)

Although most of the policies examined so far have an implicit influence on OFDI from South Africa, the government has an explicit policy framework known as the 'Gateway to Africa and Other Reforms Initiative', that although intended to attract FDI to South Africa, also influences OFDI flows to African countries through some incentives aimed primarily at TNCs South African TNCs investing in Africa. This initiative is aimed at making South Africa an economic gateway to Africa by relaxing foreign exchange controls for Africa-focused investments, and attract large international companies to use the country as a base for their forays into the continent. Thus, companies may establish one subsidiary (a HoldCo, or Holding Company) to conduct African and offshore operations, which will not be subject to 
any exchange control restrictions. In 2013 and 2014, the key arrangements made under the 'Gateway to Africa and Other Reforms Initiative' influencing or impacting OFDI were:

1. The amount a parent company may transfer to a HoldCo was increased from R750 million to R2 billion per year. Furthermore, the SARB could consider applications for transfers of up to $25 \%$ of the company's market capitalisation. However, these applications should provide evidence and demonstrate the benefits to South Africa.

2. Restrictions on transfers into and out of a HoldCo, up to the allowed amount, were removed. But, the parent company making transfers is subject to regular reporting and supervision for tax purposes.

3. The listing of a HoldCo and joint ventures are considered on a case-by-case basis.

4. All HoldCos are permitted to use a foreign functional currency, rather than South African Rands in determining their tax calculations.

5. Some tax concessions that are made annually in the National Budget are also applicable to companies that register offshore holding subsidiaries and retain a South African tax residence and management control.

The major aim of these arrangements was to streamline the promotion of OFDI from South Africa by removing the requirements to make applications to the SARB for small amounts of money and go through sometimes lengthy approval processes. These arrangements lessen the administrative burden on international firms and ease the processes associated with doing business in Africa for TNCs - thus, promoting OFDI. Although international firms have to invest in South Africa first in order to get some benefits under this initiative, South African TNCs reap some benefits under this initiative when they invest in Africa.

\section{Political factors influencing South African outward FDI flows}

The research results show that political factors indeed influence the flows of outward FDI from South Africa. The country has implicitly influenced OFDI by successfully deploying ad hoc and flexible international relations and a diplomatic approach. For instance, the Presidency and DIRCO may undertake structured trade visits abroad and arrange exhibitions that may also involve South African TNCs - hence, influence OFDI. Similarly, TISA may provide advice to South African OFDI firms, when approached. But these actions are not so co-ordinated or well-planned or solely focused on FDI that they demonstrate a clear national strategy that aims to influence outflows of FDI from South Africa.

An example where the diplomatic approach has been used to facilitate OFDI is in the case Eskom Enterprises investment in the energy sector in Uganda, which was made at the back of state visits by President Thabo Mbeki, with an entourage that included Eskom delegates (Interview, with an Eskom Enterprises Official, 1 September 2014). Similarly, a South African TNC, PetroSA, was able to sign an agreement to invest in the oil sector in the DRC during the 8th session of the SA-DRC bi-national commission that took place in Pretoria on 23 October 2012. The agreement signed between PetroSA and Cohydro Sarl of the DRC established a strategic co-operation in activities such as pre-exploration, exploration, development and production of hydrocarbons for the benefit of the two countries. Thus, through positive political and diplomatic relations, South Africa has managed to influence investments in friendly countries. 
Apart from diplomatic and international relations influencing OFDI, there is evidence that South Africa influences OFDI through the rule-based approach. Most BITs signed by South Africa with other states contain the 'objects and purpose' clause, with provisions for encouraging reciprocal investments between the states concerned and the protection of investments once made (Boulle 2010).

The rule-based approach has been used in influencing OFDI in African countries, in particular, protecting South African direct investments in Zimbabwe. South Africa and Zimbabwe have cordial political and diplomatic relations, to the extent of South Africa using the controversial quiet diplomacy when Zimbabwe engaged in the fast-track land reform process which started in 2000 (Sachikonye 2005). However, Zimbabwe's fast-track land reform resulted in the expropriation of farms of South African investors without any compensation. Instead of the South African government intervening in the matter using the diplomatic approach, it used a rule-based approach, whereby the investors were allowed to bring a series of cases in Zimbabwean and South African courts (including the Constitutional Court on technical issues) and SADC Tribunal.

The application to the SADC Tribunal was based on human rights considerations and not on technical investment law issues. The Tribunal found that Zimbabwean actions were discriminatory and unlawful in terms of the SADC Convention. This decision was repudiated by both the government and courts of Zimbabwe and had no legal effect in the jurisdiction in which the investors were seeking their farms' return. The decision was ratified by South African courts but resulted in lengthy steps to execute on Zimbabwean government property in Cape Town, ensuring some financial compensation for the investors but not the return of land. In this case, South Africa allowed the due legal process to take course, without political or diplomatic interference.

\section{Are South Africa's approaches to OFDI different from other countries?}

Although the research shows that South Africa influences OFDI through political interventions, public policies and institutional frameworks; are the country's approaches different from other FDI home countries, especially emerging countries? It is imperative to note that a number of internal and external factors at global, regional and national levels may have conditioned South Africa to influence OFDI through the explicated public policies, national institutions, diplomatic and rule-based approaches. However, the key factor that may have contributed to South Africa influencing OFDI though implicit policies and indirect institutions may be related to existing international norms set by developed countries.

The traditional and main sources of OFDI are developed western countries that have not actively regulated OFDI flows. In actual fact, most of the developed countries have essentially left TNCs to operate with minimal state intervention. This is generally in line with the attitudes of the persons living in developed countries, especially in North America and Europe that have cherished the notion of minimal state intervention in the operations of the markets (Weiss 1998). Since developed countries that have traditionally been the sources of FDI have not regulated these flows, South Africa may be considered as following the norms set by these countries. 
However, some emerging countries such as China, Brazil and Russia tend to influence outward flows of FDI through active regulation by some explicit policy frameworks and direct institutions. Explaining the direct Chinese institutions for OFDI, Luo, Xue, and Han $(2009,3)$ observes that:

There are several political and regulatory institutions in China that guide and manage Chinese OFDI. The main actors are the State Council, Ministry of Commerce (MOC), People's Bank of China, State Administration of Foreign Exchange (SAFE), State-owned Assets Supervision and Administration Commission (SASAC), and State Development and Reform Commission.

Similarly, in terms of public policies influencing OFDI, three distinct stages can be discerned, that is, Phase 1 (1984-1990), Phase 2 (1991-2000) and Phase 3 (2001-present) (Luo, Xue, and Han 2009). The first explicit OFDI policy was promulgated in China in 1984 (Zhang 2003). In 1992, political actors facilitated a change in perception and approaches to OFDI (Buckley et al. 2007). And, since 2000 the government has actively influenced investments made by Chinese enterprises in other countries. Currently, the explicit policies influencing OFDI from China can be distinguished into promotional and monitoring (Luo, Xue, and Han 2009).

Besides China, another illustrative case on an emerging country that influences OFDI through a set of explicit public policies, direct institutions and political engagements is India. UNCTAD (2007) delineates two phases in Indian outward FDI flows to other countries, namely the period before 1992; and the period from 1992 onwards. Whereas the period before 1992 was an era of restrictive but explicit OFDI policies, the post-1992 epoch has been an era of liberalised and active regulation of OFDI (Pradhan 2011). In spite of the subtle differences in policy frameworks, what is important in all the two periods is that India explicitly and directly influences the outflows of OFDI.

Another point worth highlighting is that political actors in both China are very clear on the outcomes that they desire from their TNCs as home countries (Sauvant and Pradhan 2010; Sauvant and Chen 2014). To exemplify this, the Chinese government directly influences its state-owned TNCs in investments that are strategic to China, including which sectors the TNCs invest in abroad (Luo, Xue, and Han 2009). Similarly, India also promotes and monitors its TNCs in order to ensure that the home country benefits from the proceeds of OFDI (Sauvant and Pradhan 2010). However, this is not the case with South Africa. In fact, South African policy-makers may not have seriously considered the benefits that be realised through OFDI. UNCTAD $(2005,13)$ reports that 'available evidence suggests that OFDI in general has helped increase the competitiveness of South African companies at least in terms of greater revenues, profitability, market expansion, and access to technology and exposure to international business'. Trevor Manuel in the Budget Speech in 2001 also stated that 'the global expansion of South African firms holds significant benefits for the economyexpanded market access, increased exports and improved competitiveness'.

Whilst these sentiments have been expressed, the focus of South African policy-makers as evidenced in policy documents and pronouncements has been on attracting FDI for domestic economic growth and job creation. Understanding of domestic benefits of OFDI or how OFDI can stimulate the growth of South Africa's economy through technological 
innovation and improve exports is still limited amongst policy-makers in the country. In addition, there is a general lack of country-specific empirical evidence on the benefits of South African OFDI to the country that the policy-makers can use. Overall, there is no clear understanding of whether greater regulation or a laissez faire approach to OFDI provides greater benefits to the home nation-this is an important area for future research.

\section{Conclusion}

This article has demonstrated that South Africa largely influences OFDI through implicit public policies, and indirect national institutions. In addition, the country's political activities including diplomatic and rule-based approaches influence OFDI. The study highlighted that South Africa has an explicit OFDI policy framework for African countries. The paper further analysed South Africa's approaches for OFDI are different from those used by other countries, especially emerging countries. The study shows that South African ways of influencing OFDI seem more informed by the developed western nations than other emerging countries. Although not exhaustive, illustrative case studies of China and India demonstrated that other emerging countries seem to use a different approach in influencing outflows of FDI from their territories. Whether South Africa would benefit more by departing from its current approaches to a more active regulatory approach that includes explicit policies and direct institutions as well as fashioning clear roles for political actors is still an unchartered research area. It is recommended that future studies focus on this essential topic.

\section{Disclosure statement}

No potential conflict of interest was reported by the authors.

\section{ORCID}

Albert Edgar Manyuchi http://orcid.org/0000-0001-7189-6201

\section{References}

Boulle, L. 2010. "In and Out the Bramble Bush: South Africa and the Global Investment Regime." Focus 58: 44-51.

Buckley, P. J., J. Clegg, A. R. Cross, X. Liu, H. Voss, and P. Zheng. 2007. "The Determinants of Chinese Outward Foreign Direct Investment." Journal of International Business Studies 38 (4): 499-518. doi: 10.1057/palgrave.jibs.8400277

Davies, R. 2012. Speech by the Minister of Trade and Industry Dr Rob Davies at the South African Launch of the United Nations Conference on Trade and Development Investment Policy Framework for Sustainable Development. Johannesburg: University of the Witwatersrand, July 26.

DIRCO (Department of International Relations and Co-operation). 2014. Presentation to the Portfolio Committee DIRCO. Cape Town: South African Parliament. 
DTI (Department of Trade and Industry). 2014. Trade, Export, and Investment. Accessed May 15, 2016. http://www.thedti.gov.za/trade_investment/trade_investment.jsp.

Games, D. 2004. The Experience of South African Firms Doing Business in Africa: A Preliminary Survey and Analysis. Johannesburg: South African Institute of International Affairs.

Gelb, S. 2010. "Foreign Direct Investment Links Between South Africa and China." Paper prepared for the African economic research consortium project on China-Africa economic relations. Accessed December 10, 2013. www.aercafrica.org.

Gelb, S. 2014. "South Africa's Foreign Direct Investment Links with the BRIC Countries." World Trade Institute/Mandela Institute Working Paper September. World Trade Institute, University of Bern.

Gordhan, P. 2013. Budget Speech. Accessed June 14, 2014. http://www.treasury.gov.za.

Gordhan, P. 2014. Budget Speech. Accessed June 14, 2014. http://www.treasury.gov.za.

Ikenberry, G. J. 1988. "Conclusion: An Institutional Approach to American Foreign Economic Policy." International Organization 42 (1): 219-243. doi: 10.1017/S0020818300007189

IMF (International Monitory Fund). 2009. Balance of Payments and International Investment Position Manual 6th Edition, BPM6. Washington, DC: IMF.

Jensen, N. M. 2003. "Democratic Governance and Multinational Corporations: Political Regimes and Inflows of Foreign Direct Investment." International Organization 57 (3): 587616. doi: $10.1017 /$ S0020818303573040

Kazunga, O. 2014. "Ministers in South Africa to Woo Investors." Chronicle, November 21.

Klein, S., and A. Wöcke. 2007. "Emerging Global Contenders: The South African Experience." Journal of International Management 13 (3): 319-337. doi: 10.1016/j.intman.2007.05.002

Kwinika, S. 2015. "Zimbabwe Repairs Infrastructure to Attract Investments." CAJ News Africa, April 10.

Luo, Y., Q. Xue, and B. Han. 2009. "How Emerging Market Governments Promote Outward FDI: Experience From China." Journal of World Business 45 (1): 68-79. doi:

10.1016/j.jwb.2009.04.003

Manuel, T. 2001. Budget Speech. Accessed June 14, 2014. http://www.treasury.gov.za.

Mwillima, M. 2003. "Characteristics, Extent and Impact of Foreign Direct Investment on African Local Economic Development." Social Science Research Network Electronic Paper Collection. Accessed May 15, 2016. http/ssm.com. 
Nishiura, A. 2009. "Determinants of South African Outward Direct Investment in Africa." Afrasian Centre for Peace and Development Studies Working Paper Series No. 59. Kyoto: Ryukoko University.

North, D. C. 1990. Institutions, Institutional Change and Economic Performance. Cambridge: Cambridge University Press.

Pradhan, J. P. 2011. "Emerging Multinationals: A Comparison of Chinese and Indian Outward Foreign Direct Investment." International Journal of Institutions and Economies 3 (1): 113148.

Sachikonye, L. M. 2005. "South Africa's Quiet Diplomacy: The Case of Zimbabwe." In State of the Nation 2004-2005, edited by J. Daniel, R. Southall, and J. Lutchman, 569-585. Cape Town: HSRC Press.

SARB (South African Reserve Bank). 2013. "Seventh Census of Foreign Transactions, Liabilities and Assets: 31 December 2011." Supplement to the South African Reserve Bank Quarterly Bulletin, September. Pretoria: South African Reserve Bank.

SARB (South African Reserve Bank). 2014. Exchange Control Manual, 2014. Pretoria: National Treasury.

Sauvant, K. P., and V. Z. Chen. 2014. "China's Regulatory Framework for Outward Foreign Direct Investment." China Economic Journal 7 (1): 141-163. doi: 10.1080/17538963.2013.874072

Sauvant, K. P., and J. P. Pradhan. 2010. The Rise of Indian Multinationals. New York: Palgrave Macmillan.

South Africa. Currency and Exchange Act (Act No. 9 of 1933).

South Africa. Currency and Banking Act, 1920 (Act No. 31 of 1920).

South Africa. South African Reserve Bank Act, 1944 (Act No. 29 of 1944).

South Africa. South African Reserve Bank Act, 1989 (Act No. 90 of 1989).

South Africa. South African Reserve Bank Amendment Act, 2010 (Act No. 4 of 2010).

Stopford, J. M., and S. Strange. 1991. Rival States, Rival Firms: Competition for World Market Shares. Cambridge: Cambridge University Press.

Strange, S. 1988. States and Markets. London: Pinter.

Strange, S. 1996. The Retreat of the State: The Diffusion of Power in the World Economy. Cambridge: Cambridge University Press. 
Strange, S. 1998. Mad Money: When Markets Outgrow Governments. Michigan: University of Michigan Press.

UNCTAD (United Nations Conference on Trade and Development). 1999. Foreign Direct Investment in Africa: Performance and Potential. New York: United Nations.

UNCTAD (United Nations Conference on Trade and Development). 2005. Economic Development in Africa: Rethinking the Role of Foreign Direct Investment. New York: United Nations.

UNCTAD (United Nations Conference on Trade and Development). 2007. Global Players from Emerging Markets: Strengthening Enterprise Competitiveness through Outward Investment. New York: United Nations.

UNCTAD (United Nations Conference on Trade and Development). 2010. World Investment Report, 2010: Investing in a Low-Carbon Economy. New York: United Nations.

UNCTAD (United Nations Conference on Trade and Development). 2011. World Investment Report, 2011: Non-Equity Modes of International Production and Development. New York: United Nations.

UNCTAD (United Nations Conference on Trade and Development). 2013. Investment Policy Monitor No. 9. New York: United Nations.

UNCTAD (United Nations Conference on Trade and Development). 2016. World Investment Report, 2016: Investor Nationality: Policy Challenges. New York: United Nations.

UNCTADSTAT. 2016. Accessed May 15, 2016.

http://unctadstat.unctad.org/wds/TableViewer/tableView.aspx.

Webb, B. 2007. "Kabila Tries to Woo South African Investors." IOL, June 15.

Weiss, L. 1998. The Myth of the Powerless State. New York: Cornell University Press.

Zhang, Y. 2003. China's Emerging Global Businesses: Political Economy and Institutional Investigations. Basingstoke: Palgrave Macmillan. 